\title{
ENTREVISTA
}

\section{COM PROFA. DRA. DENISE MARIA BOTELHO (UFRPE)}

Maria Anória de Jesus Oliveira Maria Nazaré Mota de Lima

Denise Maria Botelho possui Graduação em Pedagogia, pela Faculdade de Educação e Ciências Pinheirense - FECP, Mestrado em Integração da América Latina, pela Universidade de São Paulo - USP (2000) e Doutorado em Educação, pela Universidade de São Paulo USP (2005). Atualmente é Professora Associada do Departamento de Educação da Universidade Federal Rural de Pernambuco (UFRPE), desenvolvendo estudos e pesquisas no Programa de Pós-Graduação em Educação, Culturas e Identidades (PPGECI), Linha de pesquisa 1

- Movimentos Sociais, Práticas Educativo-Culturais e Identidades. É Líder do Grupo de Estudos e Pesquisas em Educação, Raça, Gênero e Sexualidades "Audre Lorde" (Geperges Audre Lorde).

Sua produção acadêmica inclui atividades de ensino, extensão e pesquisa nos seguintes campos: políticas educacionais; educação e relações raciais; gênero, sexualidades e religiões de matrizes africanas. Principais publicações: Relações Raciais na Escola: currículo, livro didático e alternativas de ensino. In: Adriana Pereira Campos; Gilvan Ventura da Silva. (Org.). A escola e suas cores: cidadania, educação e relações étnico-raciais. 4. ed. Vitória/Espírito Santo: GM Gráfica e Editora, 2011, p. 27-42; Zami, as escritas ancestrais da sororidade, em co-autoria com Tatiana Nascimento. In: Adailson Moreira, Carlos Eduardo Bezerra e Ema Maciel da Silva. (Org.). Arco-Íris revisitado: diversidade sexual em pauta. Porto Alegre: Ed. Escândalo, 2012, p. 117-136; Caminhos educativos para emancipações feministas: ancestralidades e identidades de mulheres negras de Terreiro, em co-autoria com Hulda Stadtler. Ciência \& Trópico, v. 37, p. 93-113, 2013; O enfrentamento do racismo e preconceito no Brasil: a experiência dos NEABs, em co-autoria com Moisés Santana. 21. ed. Itaja: CasAberta Ed., 2014.

Nesta entrevista, encontra-se um conjunto de questões tematizadas no Pós-Crítica, seja em reuniões de Linha, seja em uma parte significativa das dissertações concluídas e em andamento. Para nós, é um privilégio poder apresentar para os leitores e as leitoras as reflexões de Denise Maria Botelho, cuja contribuição tem sido tão grande e tão significativa, incidindo sobre a temática que escolhemos para esta edição da Revista Pontos de Interrogação. 
MA e MN: Considerando a temática do presente volume de nossa Revista, você diria que as identidades negras, hoje, já estão bem representadas nas narrativas e nas memórias brasileiras?

DMB: Hoje, conseguimos identificar um número maior de representação negra nas narrativas e nas memórias brasileiras, mas não podemos avaliar que a população negra esteja bem representada; afinal, as lacunas e deturpações que ainda ocorrem com a imagem das pessoas negras não permitem que tenhamos, nem quali e nem quantitativamente, representação positiva.

MA e MN: Após 12 anos de alteração da LDB, pela Lei Federal 10.639/03, logo, mais de uma década de obrigatoriedade da abordagem da história e cultura afro-brasileira e africana em todas as escolas do país, na sua opinião, o que há para comemorar? E para lamentar?

DMB: Primeiro precisamos entender que a obrigatoriedade não se estabeleceu, de fato, na realidade escolar brasileira. A temática História e cultura afro-brasileira e africana não é uma política educacional que foi replicada nos parâmetros educacionais dos municípios e dos estados; sendo assim, a lei federal, muitas vezes, fica muito distante das salas de aula, o conteúdo afro-brasileiro é boicotado em várias escolas do país, pela própria equipe pedagógica, que cria argumentos embasados em uma interpretação teológica excludente, intolerante e equivocada.

MA e MN: É notável a crescente produção de materiais audiovisuais acerca da cultura afro-brasileira. Você considera que essa produção vem sendo utilizada nas escolas e salas de aula? Gostaria de destacar algumas dessas produções (livros, sites, e/ou filmes, por exemplo) e comentar sua utilização como apoio pedagógico?

DMB: Cabe ressaltar que o Programa Nacional do Livro Didático tem premissas que influenciaram a alteração da utilização da imagem das pessoas negras no material didático inicialmente serão “... excluidas do PNLD 2016 as obras didáticas que: 1. veicularem estereótipos e preconceitos de condição social, regional, étnico-racial, de gênero, de orientação sexual, de idade ou de linguagem, assim como qualquer outra forma de discriminação ou de violação de direitos;” (Brasil, Edital PNLD, 2016), como também, a necessidade de retratar “... a miscigenação da população brasileira, por meio de textos e ilustrações, destacando a diversidade étni- 
co-racial como ela existe na realidade;" (Idem). A partir das exigências da política educacional para material didático, as editoras têm apresentado preocupação em atender os requisitos relacionados à questão étnico-racial, para garantir a competitividade comercial. Para além deste aspecto geral da produção de conhecimento, destaca-se, também, uma crescente produção de autoras e autores negros que estão vinculando em suas obras o contexto afro-brasileiro de forma central, possibilitando uma ampliação significativa de obras literárias que subsidiam educadores/as em suas práticas pedagógicas direcionadas para a diversidade étnico-racial em sala de aula.

MA e MN: Em relação à formação inicial de professores/as na temática, como a universidade vem cumprindo a parte que lhe cabe, e o que merece sua crítica?

DMB: Não poderia falar sobre as universidades brasileiras, mas penso ser interessante destacar iniciativas que privilegiam a formação de professoras e professores para o trato com a questão racial e, neste caso, aponto a iniciativa do Núcleo de Estudos Afro-Brasileiros que, em parceria com o Fórum das Licenciaturas, ambos da UFRPE, conseguiram introduzir no currículo de todos os cursos de licenciaturas, obrigatoriamente, a disciplina "Educação das relações-raciais", e como optativa para os bacharelados. Tal iniciativa foi um desdobramento da disciplina "Educação afro-brasileira", que já era oferecida como disciplina optativa para os/as estudantes do Curso de Licenciatura Plena em Pedagogia daquela universidade. Destaco também as iniciativas da UnB, com a disciplina "Pensamento negro contemporâneo", e da UFSCAR, com a disciplina "Didáticas e educação das relações étnico-raciais".

MA e MN: A intolerância religiosa, sabemos, é um dos grandes entraves para fazer valer a Lei 10.639/03 nas escolas. Comente essa complexa questão e os possíveis problemas diante dessa e outras intolerâncias.

DMB: A estrutura educacional brasileira, de verdade, não tem uma prática de gestão democrática, como preconiza a LDB e, muitas vezes, a direção tem uma ação autoritária e discriminatória em relação à história e cultura afro-brasileira, africana e indígena (Leis 10.639/2003 e 11.645/2008), impedindo a introdução destes conteúdos no currículo da escola. Posturas discriminatórias e excludentes são resultado da compreensão equivocada de que os segmentos afro-indígenas são contrários aos ensinamentos cristãos e, portanto não devem ser incluídos, mas sim combatidos nos espaços educacionais. Tal compreensão reflete a fragilidade dos cursos de formação para o magistério, em relação aos aspectos socioantropológicos da 
realidade brasileira, como também a falácia de um Estado laico, que permite a intolerância religiosa nas escolas públicas em relação às religiões de matrizes africanas.

MA e MN: Fale como foi o processo de institucionalização da obrigatoriedade do ensino sobre relações étnico-raciais na UFRPE, através de disciplina obrigatória em todas as licenciaturas e optativa em todos os cursos da universidade.

DMB: Inicialmente, foi ofertada a disciplina "Educação afro-brasileira" para o Curso de Pedagogia, por preposição do professor Moisés Santana; depois o coletivo de membros do NEAB-UFRPE entendeu que a experiência da Pedagogia era bastante positiva e deveria ser ampliada para as demais licenciaturas da universidade. Sendo assim, elegeu-se o Fórum das Licenciaturas para discussão da proposição de uma disciplina de educação das relações raciais. Em diversos encontros foi discutida a proposta de alteração do currículo das licenciaturas, com a inclusão da referida disciplina e, em maio de 2011, o NEAB e o Fórum realizaram um seminário geral para os(as) coordenadores de cursos para apresentação da proposta da disciplina. Participaram do seminário representação institucional da SEPPIR, especialistas da área de educação étnico-racial. Ao final, compreendeu-se, pela maioria do coletivo, que a disciplina deveria ser aprovada. Daí, foram realizados os trâmites burocráticos para a criação da disciplina, vinculando-se a necessidade de abertura de concurso público para seleção de docentes para ministrar o novo componente curricular.

Recebido em 12 de agosto de 2015.

Aceito em 21 de setembro de 2015. 